\title{
Nuevas miradas sobre la creación artística de Carlos Foresti ${ }^{1}$
}

\author{
New views about the \\ artistic creation of Carlos Foresti \\ DusAn MartinOVIC ANDRADE* \\ ${ }^{a}$ Museo Regional de Magallanes, Servicio Nacional de Patrimonio Cultural \\ $\checkmark$ dusan.martinovic@museosdibam.cl
}

\begin{abstract}
RESUMEN
En este artículo se describe y analiza el trabajo artístico desarrollado en territorio patagónico, y particuarmente en Magallanes, por el fotógrafo italiano Carlos Foresti, llevado a cabo fundamentalmente a inicios del siglo XX, pesonaje que se ocupó de retratar de forma detallada las actividades económicas y sociales de estos territorios. Se plantea a modo de hipótesis, que su obra ha sido escasamente valorada, lo que podría estar relacionado con su cercanía a los círculos de poder económico, representado por las empresas del rubro ganadero, comerical y cabotaje. Las fuentes utilizadas corresponden a una serie de álbumes fotográficos, revistas y obras pictóricas, las que se han sido habidas en repositorios documentales de Argentina (Trelew) y Chile (Santiago, Punta Arenas).
\end{abstract}

PALABRAS CLAVE: Foresti, fotografía, reportero, artista, estancia, industria, Magallanes.

\begin{abstract}
This article describes and analyzes the artistic work developed in Patagonian territory, and particulary in Magallanes, by the Italian photographer Carlos Foresti, carried out fundamentally at the beginning of the 20th century, character that took care to portray in a detailed way the economic activities and of these territories. It is hypothesized that his work has been scarcely valued, according to his relationship with the circles of economic power, represented by the livestock, commercial and cabotage companies. The sources used

1 Este trabajo se realizó en el contexto del "Fondo de apoyo a la investigación patrimonial de la DIBAM", año 2016, convocado por el Consejo de Investigación del Centro de Investigación Barros Arana, Biblioteca Nacional de Chile.
\end{abstract}




\section{MARTINOVIC}

correspond to a series of photographic albums, magazines and pictorial works, which have been found in documentary repositories of Argentina (Trelew) and Chile (Santiago, Punta Arenas).

KEY WORDS: Foresti, Photography, Journalist, Artist, Stay, Industry, Magellan.

\section{INTRODUCCIÓN}

"Tiene nuestra revista, la suerte de contar en preferente lugar entre sus corresponsales gráficos a un notable 'amateur' de la cámara fotográfica que ha sido verdaderamente el revelador de las inmensas bellezas que encierran las rejiones desconocidas del sur de nuestro continente (...).

El señor Foresti es un poeta de las bellezas agrestes de los valles, de la cordillera, de las costas y canales de Magallanes al Sur. A él se debe la reproducción intelijente y realísimas de lagos y ventisqueros, de montañas y cascadas de esos países perdidos durante siglos entre las brumas de la leyenda (...)” (Revista Zig-Zag, 1907).

Carlos Foresti fue un inmigrante italiano que arribó a América hacia fines del siglo XIX, para posteriormente alcanzar Patagonia, lugar donde se inserta laboramente como agente de ventas, para posteriormente dedicarse a diversos trabajos, tales como, corresponsal, fotógrafo, ilustrador, incursiando incluso en la pintura. Fue así, que en el contexto de la ejecución de tales actividades, dejaría para la posteridad una serie de trabajos artísticos que se configurarían como vívidas respresentaciones del teritorio patagónico de las primeras tres décadas del siglo veinte, algunos de los cuales son ampliamente conocidos, en tanto que otros permanecen casi en el anonimato.

Este artista gráfico italiano, desarrolló la fotografía comercial, como también la fotografía periodística, imágenes publicadas en diversas revistas nacionales y extranjeras. Fue un comerciante en el sentido de que logró poner a la venta álbumes fotográficos sobre territorios específicos, generalmente con el apoyo económico de las autoridades locales. Incursionó también en la pintura y el dibujo, aspecto escasamente conocido, cuyo valor radica en que tales trabajos, encumbran a Forestti como uno de los primeros representantes de los círculos culturales del territorio Magallánico de inicios del siglo XX.

La obra de Carlos Foresti ha estado marcada por la incomprensión, debido a que históricamente ha sido catalogado como un fotógrafo publicitario, de modo que prácticamente se desconoce la riqueza de su fotografía, espacio donde logra plasmar el ethos social del Magallanes de inicios del siglo XX. Lo mismo ocurre en la pintura donde su obra transita entre el dibujo y el retrato al óleo, o con sus trabajos en revistas tan importantes como Mireya y Zig-Zag, donde de igual manera, demostró sus cualidades artísticas. Foresti destaca entre los fotógrafos de la época por su dinámico transitar entre las diferentes representaciones de la 
fotografía, dominando diversas técnicas e incursionando en nuevos productos como tarjetas postales o álbumes impresos.

Para comprender las motivaciones y la trascendencia de su obra, en este artículo se describe el trabajo desarrollado por Foresti como corresponsal viajero de la revista Caras y Caretas, editada en Argentina, y se analiza su trabajo en los álbumes fotográficos editados en aquel país a fines del siglo XIX y otros tres álbumes publicados en la Patagonia chilena en 1900, 1918 y 1920, con el fin de dar cuenta de su legado patrimonial y artístico.

La obra de Foresti, bien podría ser calificada como la de un fotógrafo profesional, por cuanto se llegó a transformar en un amplio conocedor e impulsor de técnicas innovadoras para el concierto magallánico, tales como el fotomontaje o la coloración de imágenes, así como también la aplicación de la colotipia, también conocida como fotolitografía o fotograbado.

Sin embargo lo anterior, su trabajo es conocido y encasillado como propio de un fotógrafo innovador en el rubro comercial. Si bien es cierto, el territorio de Magallanes posee una serie de atributos que lo hacen propicio para el desarrollo de obras paisajísticas, fotografía social o documental, Foresti retrata de forma muy detallada las actividades económicas y sociales de estos territorios, promocionando con su obra, establecimientos y emprendimientos comericales, cuyos propietarios eran en definitiva, quienes contrataban y financianan su trabajo. Esta labor fotográfica, será un valioso complemento que enriquecerá gráficamente las guías comerciales, indicadores productivos o censos, que retratan un siglo después las características económicas de esta zona de la Patagonia.

En este artículo, se plantea a modo de hipótesis que la obra gráfica de Foresti ha sido escasamente considerada y valorada en su mérito artístico, dada su cercanía con los círculos de poder económico, representados fundamentalmente por las familias Braun y Menendez², sus principales empleadores, y en tal sentido, se plantea, a la luz de la recopilación y análisis de la amplia obra de este artista italiano, que con su trabajo se encumbra como uno de los primeros exponente del círculo artístico-cultural del territorio de Magallanes de inicios del siglo XX.

En función de lo anterior, se tiene por objetivos analizar la obra de Foresti, dando cuenta de las variadas temáticas de su producción artística. Seguidamente se busca elaborar un catastro de los trabajos fotográficos y pictóricos presentes en la Patagonia como área de desarrollo del artista. De igual modo, se busca entregar nuevos antecedentes referidos a la labor artística del fotógrafo italiano, contribuyendo a colmar los vacíos de información respecto de su obra.

Metodológicamente, se llevó a cabo un análisis histórico (longitudinal) e interpretación crítica o hermenéutica clásica del trabajo de Carlos Foresti, a partir de dos vertientes, las que fueron seleccionadas por razón de amplitud de ejemplares y temáticas abordadas, a

Respecto de éstos personajes que llegaron a conformorar verdaderos oligopolios en variados rubros de la economía patagónica, existen visiones contrapuestas a la hora de valorar su aporte al devenir económico-social. Ver: Alonso (2014), Harambour (2017) y Martinic (2001). 


\section{MARTINOVIC}

saber: vertiente artística contenida en su obra fotográfica, íntegramente analizada en base a los diversos álbumes que editó, y una segunda línea, en base al trabajo pictórico del artista italiano.

Los antecedentes referidos a la vida y quehacer del artista de origen florentino, fueron recopilados en revistas y álbumes fotográficos privados o corporativos, antecedentes allí plasmados por terceros e incluso provenientes del propio fotógrafo. Complementariamente, la revisión y catalogación de la fructífera y escasamente conocida trayectoria fotográfica, se desarrolló a partir de una serie de artículos periodísticos publicados sobre la Patagonia a inicios del siglo XX, escritos donde Foresti destaca como corresponsal de varias revistas nacionales e internacionales, como en la serie de álbumes fotográficos en los que incluye su propia producción artística por medio de dibujos, óleos y acuarelas.

Las fuentes documentales utilizadas fueron obtenidas de los repositorios documentales: Archivo fotográfico Museo Regional de Magallanes, Punta Arenas; Departamento de Colecciones especiales y digitales, Biblioteca Nacional, Santiago; Biblioteca Gabriel A. Puentes de la Universidad Nacional de la Patagonia San Juan Bosco, Trelew, Argentina; Archivo personal Mateo Martinic.

Específicamente se tuvo acceso a la obra de Foresti expresada en álbumes fotográficos, los que abarcan el periodo 1900-1920, a saber: 'Chile-Argentina. Tierra del Fuego. Patagonia', ‘Álbum Casa Braun y Blanchard' (1909), 'Álbum Punta Arenas Recuerdo' (1900), 'Álbum vistas de las estancias “Glencloss y Laurita' (1909), 'Álbum Chubut' (1903) y 'Álbum vistas del frigorífico Puerto Bories’ (1918), álbun “Territorio de Magallanes, 1920”; en cuanto a obras pictóricas, se tuvo a la vista la obra Hernando de Magallanes, y otra docena de obras representadas en álbumes y revistas, invidualizadas más adelante.

\section{Carlos Foresti: Artista y fotográfo y su aparición en territorio patagónico}

Carlos Foresti Casalli fue un comerciante italiano nacido en Florencia en el año 1872. Viaja a América como miles de inmigrantes del viejo continente, buscando un desarrollo económico que en su patria le había sido esquivo. Ingresa a América vía el puerto de Buenos Aires el 24 de octubre de 1897 y se identifica en su papeleta de migración como italiano, casado y de profesión comerciante.

Su estadía en Buenos Aires es corta, ya que viaja rápidamente al sur de Argentina, pero este breve paso por la cosmopolita capital será muy prolífico en lo que a contactos profesionales se refiere, ya que es una ciudad con una alta inmigración italiana que le abre nuevas posibilidades de trabajo. Aparece su faceta comerciante al ser reclutado como agente de ventas de la recién creada Revista Caras y Caretas, semanario de actualidad, con un fuerte contenido de humor político amenizado por fotografías y un gran número de caricaturas. Obtendrá así su primer trabajo en América. No existen antecedentes sobre su formación artística o fotográfica, aunque debido a sus trabajos iniciados apenas llegó a América, 
podemos suponer que estos conocimientos vienen desde Europa.

Carlos Foresti aparece en la escena fotográfica en Patagonia, como agente de ventas y corresponsal de la Revista Caras y Caretas. Esta revista cuyo primer número aparece en 1898, alberga las primeras noticias del turista y fotógrafo italiano. Existen un par de informes referidos a la Provincia del Chubut, con noticias de inundaciones de aquella provincia argentina, pero también comienzan a aparecer artículos generados desde Magallanes, por lo que se puede seguir el transitar del fotógrafo a través de sus publicaciones, ya que tiene la poco común característica de retratarse en muchos de sus artículos, en el lugar de los sucesos.

La primera noticia magallánica es un artículo denominado "De Punta Arenas. Descubrimiento de una Mina de Carbón", aparecido en el número 128, del 16 de Marzo de 1901, en la cual aparecen cuatro magníficas imágenes en las que se puede apreciar al propio Foresti retratado en estas fotografías.

En Octubre de 1901 otro amplio reportaje aparece con las instantáneas de Carlos Foresti; son las noticias referidas a la inundación de la Provincia del Chubut, lo que demuestra que el autor de las fotografías cumplía a cabalidad con su apelativo de "turista fotógrafo", ya que las tomas de aquel fenómeno climático fueron captadas por Foresti in situ, comprobando su movilidad por la Patagonia chileno-argentina.

Foresti no poseía grandes capacidades de composición o equilibrio en las imágenes, ni manejaba el paisajismo por sobre sus pares, solo se centraba en obtener retribución comercial fruto de sus trabajo, y es por ese motivo que se relacionaba y fue contratado durante toda su estadía en Magallanes por los grupos económicos dominantes del territorio, poseedores de la gran industria ganadera y comercial local.

Es importante destacar la utilización de técnicas como el coloreado, técnica que llevó a destacarlo como pionero de esta habilidad en Magallanes, cuya utilización respondía

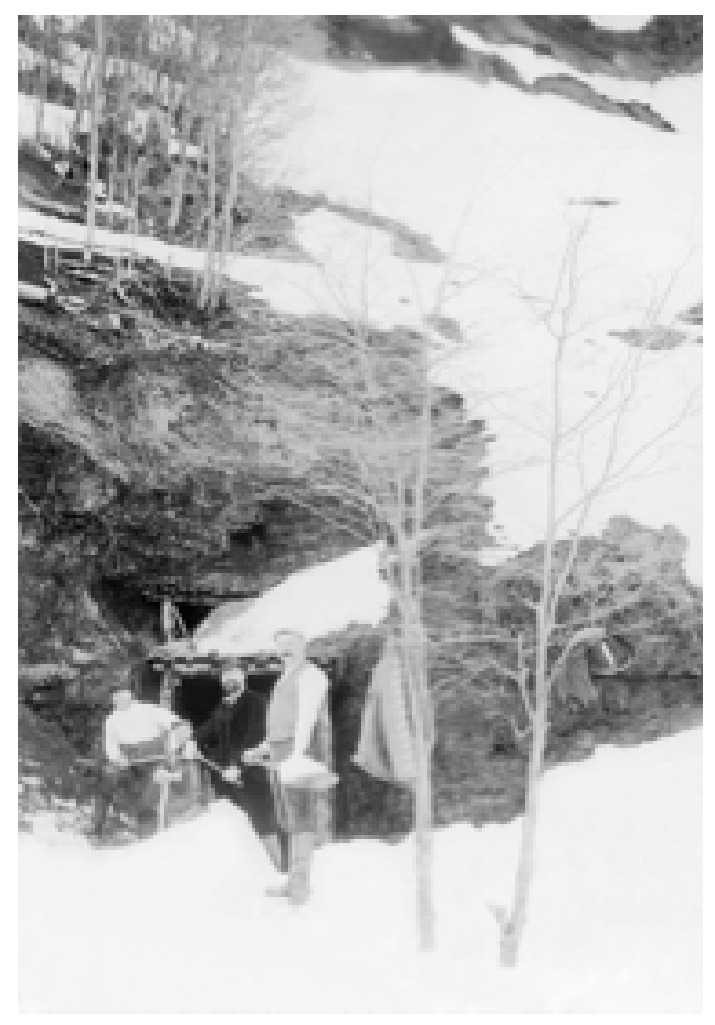

Fig. 1. Descubrimiento de una Mina de Carbón, Revista Caras y Caretas, N¹28, Carlos Foresti, Punta Arenas, 16 Marzo 1901. netamente para efectos estéticos, con el fin de mejorar y hacer más atractivo un producto fotográfico, más que obtener un valor artístico en el producto final.

El inicio de su carrera como corresponsal de un medio nacional, se da en la mítica 
Revista Zig-Zag, fundada en el año 1905 por el entonces dueño de El Mercurio, Agustín Edwards Mac-Clure. Zig-Zag rompió con todos los estándares conocidos, llegó a todo el país y su lanzamiento y promoción fue bastante atrevido para la época: para anunciar el primer número se imprimieron en Nueva York cien mil carteles. Para efectos publicitarios anexos, se contrataron gigantes propagandas y una red de suplementeros distribuyó en las principales ciudades del país.

Foresti llegaba a trabajar a un gran medio, como parte del equipo fotográfico que inició la revista ya que en el propio 1905 año de su fundación, Foresti se presenta en la capital dejando constancia "que era dueño de una de las mejores máquinas del continente" (Rodriguez, p. 2001).

En este destacado magazine existen variadas imágenes correspondientes a la época de Foresti en Magallanes, que hablan precisamente de este territorio, pero que no identifican la autoría de las fotografías. Sin embargo, son reconocibles varios interesantes artículos, redactados y complementados con fotografías propias, entre ellos un artículo de 1905, que hace referencia a Punta Arenas titulado "La Suiza de Sudamérica”, y dos de 1907 "La Noruega Chilena, vista de los canales del sur" y el más interesante en lo que a fotografía se refiere, que se denomina "Una raza que se extingue".

A contar del año 1924, Foresti aparece trabajando en la Revista Menéndez Behety, publicación ilustrada editada bajo el alero de la Sociedad Anónima Ganadera y Comercial Menéndez Behety. Durante los primeros años (1924-1926) es básicamente un catálogo de productos a la venta en el comercio que patrocinaba la publicación, con el tiempo fue tomando un carácter editorial más enfocado a las noticias, y transformándose en un magazine que junto con publicitar sus productos comerciales, se complementaba con interesantes artículos de actualidad de Magallanes, Chile y el mundo.

Los más señeros trabajos del fotógrafo italiano en la Revista Menendez Behety, se concentran en 1928, específicamente en los números 58-59 y 60, donde aparecieron una serie de artículos titulados "Punta Arenas de hace 30 años", en los cuales se reproduce el álbum "Punta Arenas Recuerdos del año 1900", donde su autor tenía como objetivo graficar el progreso de la ciudad en aquel entonces.

Nuevos antecedentes referidos a Carlos Foresti y su amistad con Gabriela Mistral

Carlos Foresti formó parte del grupo más destacado de cultores del arte en la zona magallánica a finales de la segunda década del siglo XX, si bien los diferentes autores han hecho hincapié en lo poco sobresaliente de sus creaciones artísticas, tal como lo grafica Martinic: "Para entonces, lustro final de los años 10, actuaba en el medio social puntarenense maestros de tanta calificación como el catalán Enrique Artigas Vendrell, o como Carlos Foresti, de menor relieve comparado con aquel" (2013, p. 252).

A pesar de la poca valía artística atribuida al trabajo de Foresti, su fama debió de 


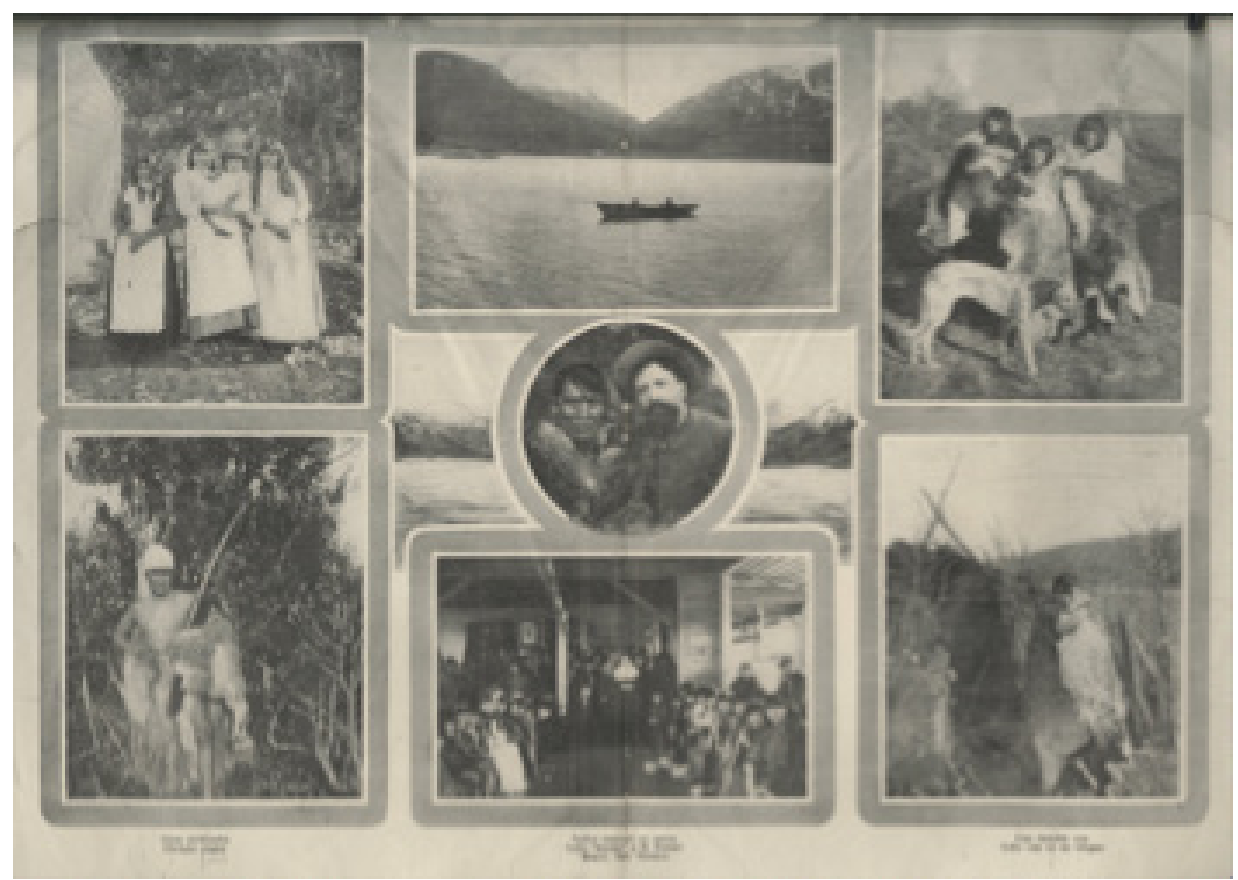

Fig. 2. Una Raza que se Extingue, Misiones Isla Dawson, en Revista Zig-Zag Nro. 101 del 27 Enero 1907, Carlos Foresti.

llamar la atención de la Directora del Liceo de Niñas de Punta Arenas (1918-1920), la futura Premio Nobel de literatura Gabriela Mistral. Foresti conoce a la insigne poetisa en la capital magallánica en 1918, ya que su hija Alba Foresti, era alumna de ésta mientras sustentaba el cargo de directora del mencionado establecimiento educacional.

La cercanía de la relación entre el fotógrafo y la poetisa se ve reflejada a través de una serie de imágenes en que aparecen juntos en la casa de Carlos Foresti.

En el álbum de Foresti de 1920, de la decena de fotografías referidas a instituciones educativas formales que allí aparecen contenidas, la única personificada por medio de un cuerpo docente y directivo es la que hace referencia a Gabriela Mistral como directora del Liceo de Punta Arenas, excepción muy bien lograda en que aparece la poetisa junto a parte de sus profesoras, entre ellas la posteriormente destacada escultora Laura Rodig.

Análisis de la obra gráfica de Forestti a través de los albumes fotográficos

Carlos Foresti editó álbumes fotográficos en Punta Arenas que se convirtieron en una nueva forma de comercializar sus fotografías, ya había innovado en la edición de tarjetas postales, ahora busca condensar en un solo objeto una temática particular, centrada en una ciudad, provincia, empresa o cualquier otra materia atractiva para reproducir por medio de un álbum.

Es interesante ver que Foresti edita sus fotografías en un álbum impreso y encuadernado 
que condensa en una hoja, fotografía e información, a diferencia de los otros álbumes conocidos de la misma época en Magallanes que se centran en temáticas familiares, (Álbum José Menéndez, Ana Braun) o en negocios (Álbum Estancia Vizcachas 1894-1924, Puerto Yartou 1915-1935) y que se presentan con fotografías individuales adheridas manualmente.

Foresti muestra una marcada evolución en cuanto al desarrollo de los álbumes de fotografías. Los primeros eran muy sencillos, con 40 o 50 imágenes empastadas en un pequeño cuadernillo en formato 23x16 cms, para luego abarcar otros de gran formato, con más de un centenar de fotografías combinadas con dibujos y acuarelas.

\section{Álbum "Punta Arenas recuerdo 1900"}

Es el primer álbum fotográfico realizado por Carlos Foresti, de formato pequeño, integrado por cuarenta y tres imágenes de la ciudad de Punta

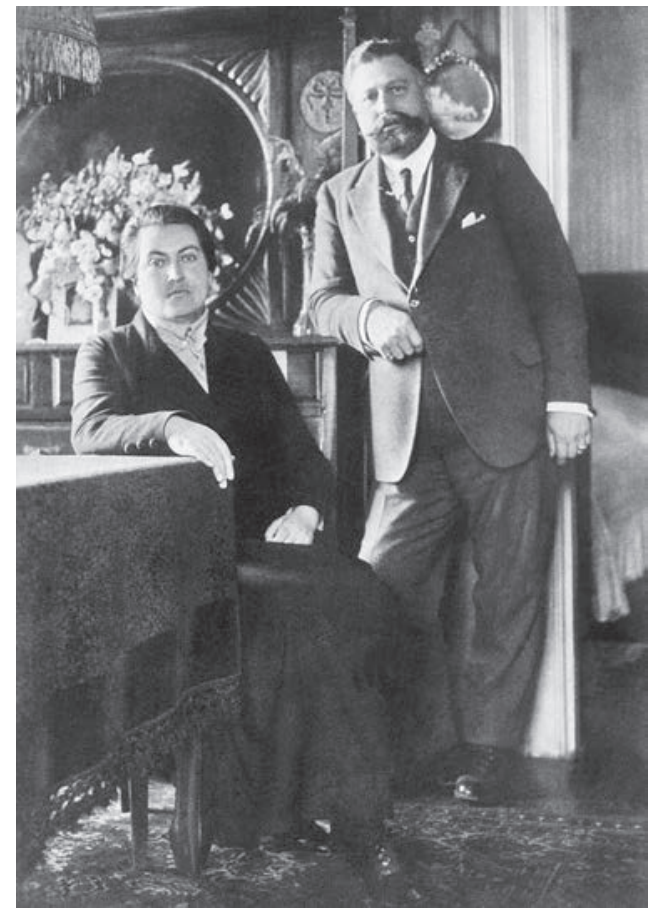

Fig. 3. Gabriela Mistral y Carlos Foresti, en Álbum Territorio de Magallanes 1920, Carlos Foresti, 1920.

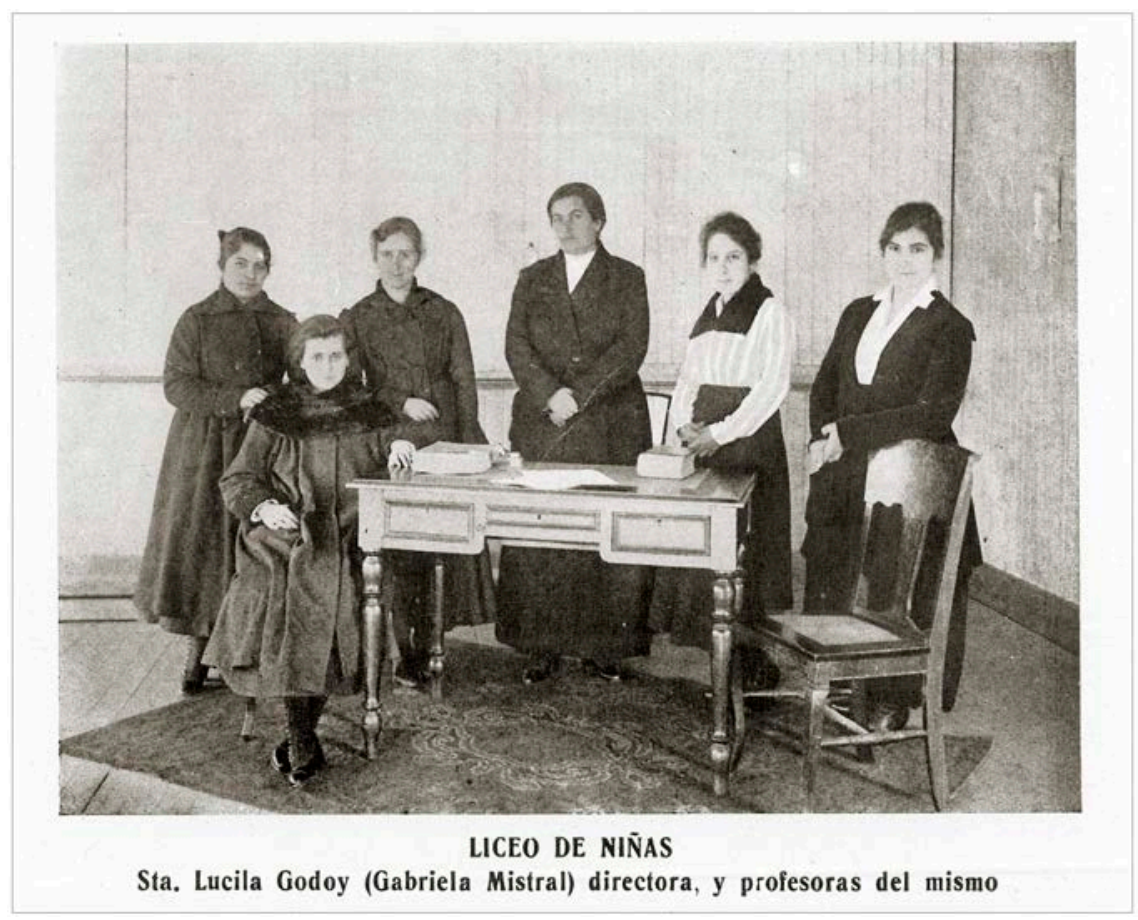

Fig. 4. Directora del Liceo de Niñas, Lucila Godoy Alcayaga, en Álbum Territorio de Magallanes 1920, Carlos Foresti, 1920. 
Arenas, entre las que destacan aquellas referidas a las principales edificaciones existentes para inicios del siglo XX.

Una naciente ciudad moderna, con edificaciones en proceso constructivo, marcan este álbum que guarda imágenes de los principales servicios que la ciudad ofrece (astilleros, comercios, bancos, hoteles, cafés, farmacias, etc).

Se asemeja mucho a una guía comercial ya que se detallan los avances más importantes de la ciudad, a modo de conjunto de imágenes descriptivas de servicios que puede entregar una ciudad al inmigrante, viajero o inversionista.

Las oportunidades se ven representadas a través de edificaciones, que se aprecian generalmente con movimiento de personas, lo que entrega un carácter de ciudad dinámica y en pleno progreso a la pequeña y cosmopolita Punta Arenas.

Las edificaciones son en su mayoría de madera con chapa de zinc, cerca de treinta imágenes corresponden a construcciones con esta materialidad, y son sólo siete las referidas a edificios de ladrillo, de las cuales dos de ellas aparecen en el álbum en pleno proceso constructivo, por lo que muestra efectivamente una ciudad en proceso de cambio. Esta situación ha sido recogida por Baeriswyl (2001), quien apunta que se produce un proceso de transición en la técnica constructiva, acicateada por el progreso material del territorio magallánico de inicios del siglo XX, pasando de la utilización de madera como material fundamental, a la aparición de una serie de edificaciones tales como, mansiones residenciales, establecimientos comerciales, bancos, bodegas, despachos, edificios públicos, religiosos y de servicios, construidos sobre la base de albañileria de ladrillos (p. 14).

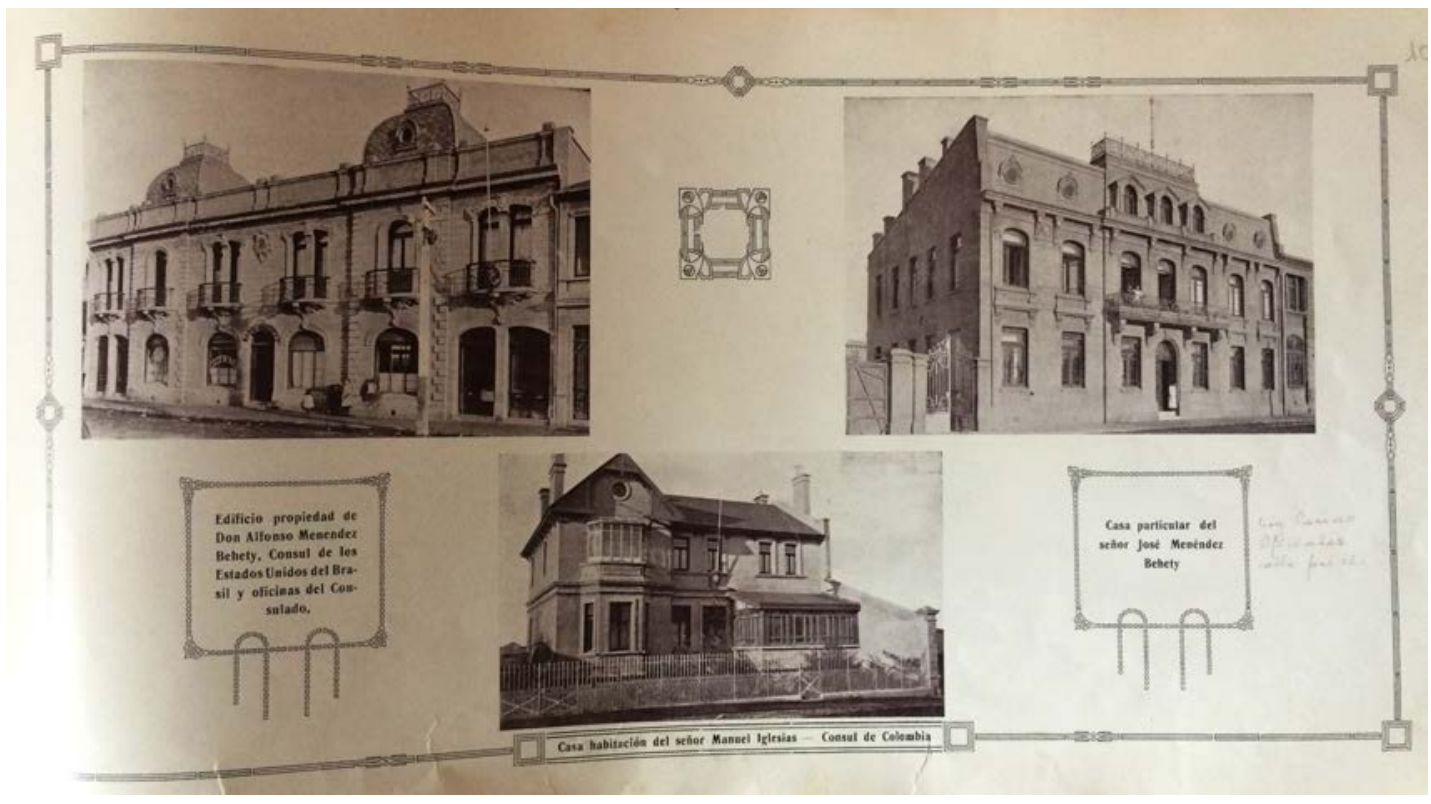

Fig. 5. Residencias José Menéndez (empresario patagónico, fundador de la "Anónima"), Alfonso Menéndez Behety (hijo del anterior y Consúl de Brasil) y Manuel Iglesias (consúl de Colombia), Álbum Territorio de Magalanes 1920 , Carlos Foresti. 
Existen registros de Foresti en la Provincia del Chubut durante los años 1902 y 1903, años en los que planeó una expedición cuya finalidad era la de retratar un territorio muy poco representado en fotografía, entendiendo la oportunidad de capturar por medio de su cámara los amplísimos territorios de esa provincia Argentina, en gran medida despoblada.

El álbum dista mucho de representar íntegramente el amplio territorio chubutense, 63 imágenes centradas principalmente en la costa le quitan protagonismo a la enorme meseta interior con su diversidad de paisajes, entregando preponderancia de las imágenes referidas a los progresos que quería poner en relieve el autor por medio de este álbum fotográfico, que a diferencia del anterior editado por Foresti (Punta Arenas recuerdos 1900), hace referencia a una ciudad específica, en relación al álbum Chubut que hace referencia a toda una provincia, a un territorio, más que a una ciudad, por lo que la limitación de su trabajo fotográfico solo a la actividad productiva es llamativa, ante lo que propone como título el Álbum. Esto se puede entender mejor comprendiendo el foco económico presente en este tipo de trabajo, como bien lo relata Pablo Lo Presti historiador del territorio chubutense que en 2014 analiza este álbum "Lo mismo ocurre con los actores retratados. Foresti fotografía todas las tolderías y asentamientos que se cruza en su camino, logrando imágenes que son formidables. Pero en el álbum no encontramos un morocho ni por casualidad... como el territorio de la meseta central, estos actores son lisa y llanamente suprimidos del discurso" (Villar, 2014).

El álbum tiene una estructura que comienza con una imagen del Presidente Argentino Julio Roca, hecho que se reiterará en los otros álbumes cuya finalidad era retratar Provincias o territorios específicos, todos comenzarán protocolarmente con la imagen del gobernador de esos territorios.

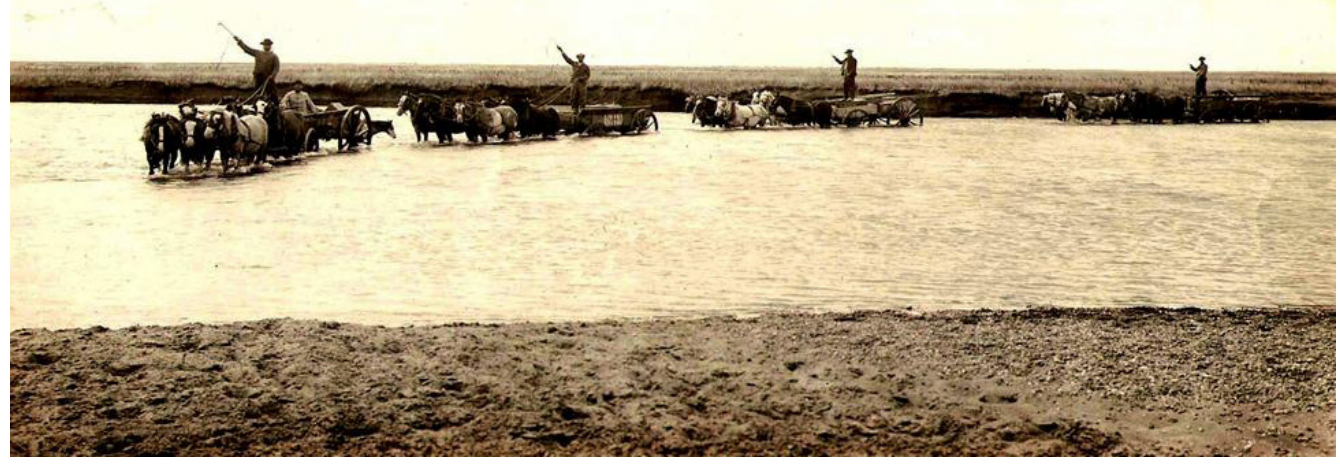

Fig. 6. Carreros vadeando el río Senguer, Álbum Chubit 1903, Carlos Foresti. 
Álbum “Chile - Argentina. Tierra del Fuego. Patagonia. Casa Braun y Blanchard, 1909”

Álbum del mismo formato que sus antecesores $23 \times 16 \mathrm{cms}$, sólo que posee escasas 15 fotografías; es una representación gráfica del quéhacer económico de la Compañía Braun y Blanchard.

Muestra con mucha claridad las diferentes casas y dependencias de la firma tanto en territorio chileno (Magallanes) como argentino (Santa Cruz). Puertos, depósitos, lugares de venta de productos y embarcaciones, son las diferentes vistas presentes en esta compilación.

La autoría (por lo menos parcial) por parte de Carlos Foresti en este álbum se evidencia a través de fotografías que pertenecen al Álbum "Punta Arenas Recuerdo de 1900", lo que unido a la similitud de tipografía y formato hacen suponer la intensa participación del turista fotógrafo en este proyecto. Aquello da cuenta de la estrecha colaboración con una de las más importantes empresas patagónicas, a la cual estará ligado por medio de otros trabajos en el transcurso de su vida.

Álbum "Vistas de las estancias

“Glencross y Laurita' 1909”

Álbum que marca un giro en las publicaciones hasta ese entonces realizadas por Foresti, este posee un formato diferente de $40 \mathrm{x}$ $23 \mathrm{cms}$, apaisado, con cubierta vinílica de color café.

Éste tiene como el anterior un evidente enfoque empresarial, hace referencia a un producto agro industrial que desea ser visibilizado, ser conocido como "eficiente", marcando una considerable diferencia con los álbumes iniciales que sólo eran vistas de un territorio.

Desarrollado en impresión halftone, muy común a principios de siglo, a partir de matriz fotográfica de fotomontaje coloreado. Posee ya no sólo fotografías, sino acuarelas, fotografías coloreadas y dibujos al carboncillo, lo que

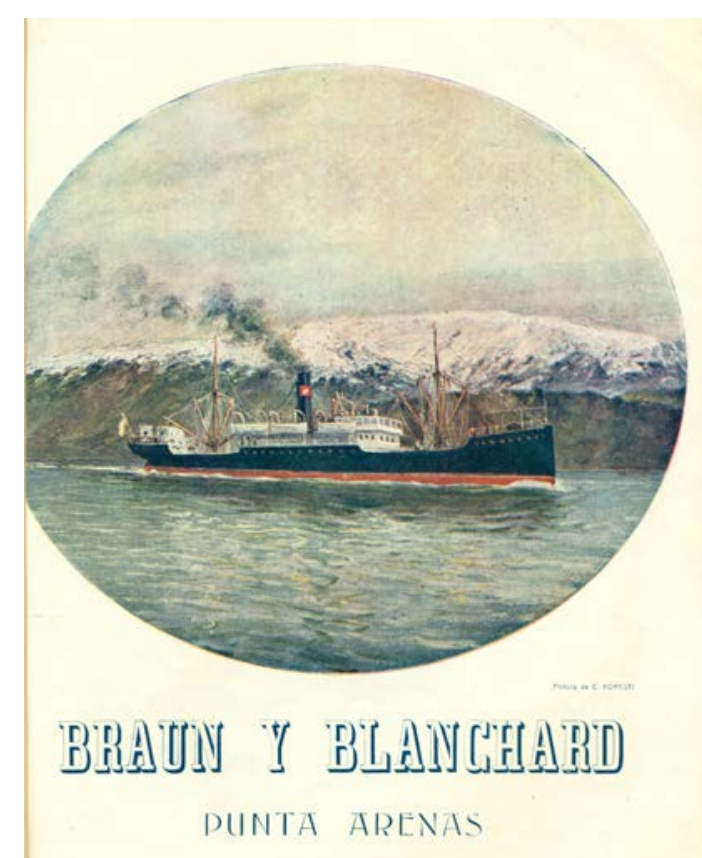

Fig. 7. Publicidad incluida en La Revista de Chile, Buenos Aires, Noviembre 1920 año II. Carlos Foresti. demuestra que Foresti comienza a divulgar, por medio de su producto característico -el álbum fotográfico-, su faceta más íntima, referida a su producción artística.

Sus pinturas coloreadas y dibujos carecen de una técnica acabada, pero entregan al Álbum un dinamismo inexistente en sus trabajos anteriores. 
Este álbum es un producto financiado por los propietarios de las estancia "Glencross" y "Laurita" los hermanos Alejandro y José Menéndez Behety, que recién ese año se habían hecho con las Estancias, comprándolas a la Compañía Pastoril Glencross en el año 1909.

\section{Álbum "Compañía Comercial y Ganadera Chile - Argentina"}

Sin fecha de publicación, este álbum data probablemente de 1910, también en formato grande de $35 \times 22.5 \mathrm{cms}$.

Contiene setenta y cinco fotografías individuales distribuidas en sus 75 hojas de extensión, 24 imágenes en territorio chileno, tanto en Puerto Montt como en Puerto Varas, y 51 fotografías en territorio argentino, principalmente de San Juan de Bariloche y sus alrededores.

La Compañía Chile-Argentina, que constituye un caso paradigmático por la magnitud de sus inversiones y negocios, inusuales para la zona y para la época. Sus operaciones económicas a escala regional y patagónica impactaron en San Carlos de Bariloche, marcando el ritmo de las prácticas sociales y económicas de la región del gran lago por casi dos décadas.

Esta sociedad llegó a ser la poseedora de la mayor superficie de tierra concentrada por un solo dueño en territorio neuquino, de 419.737 hectáreas.

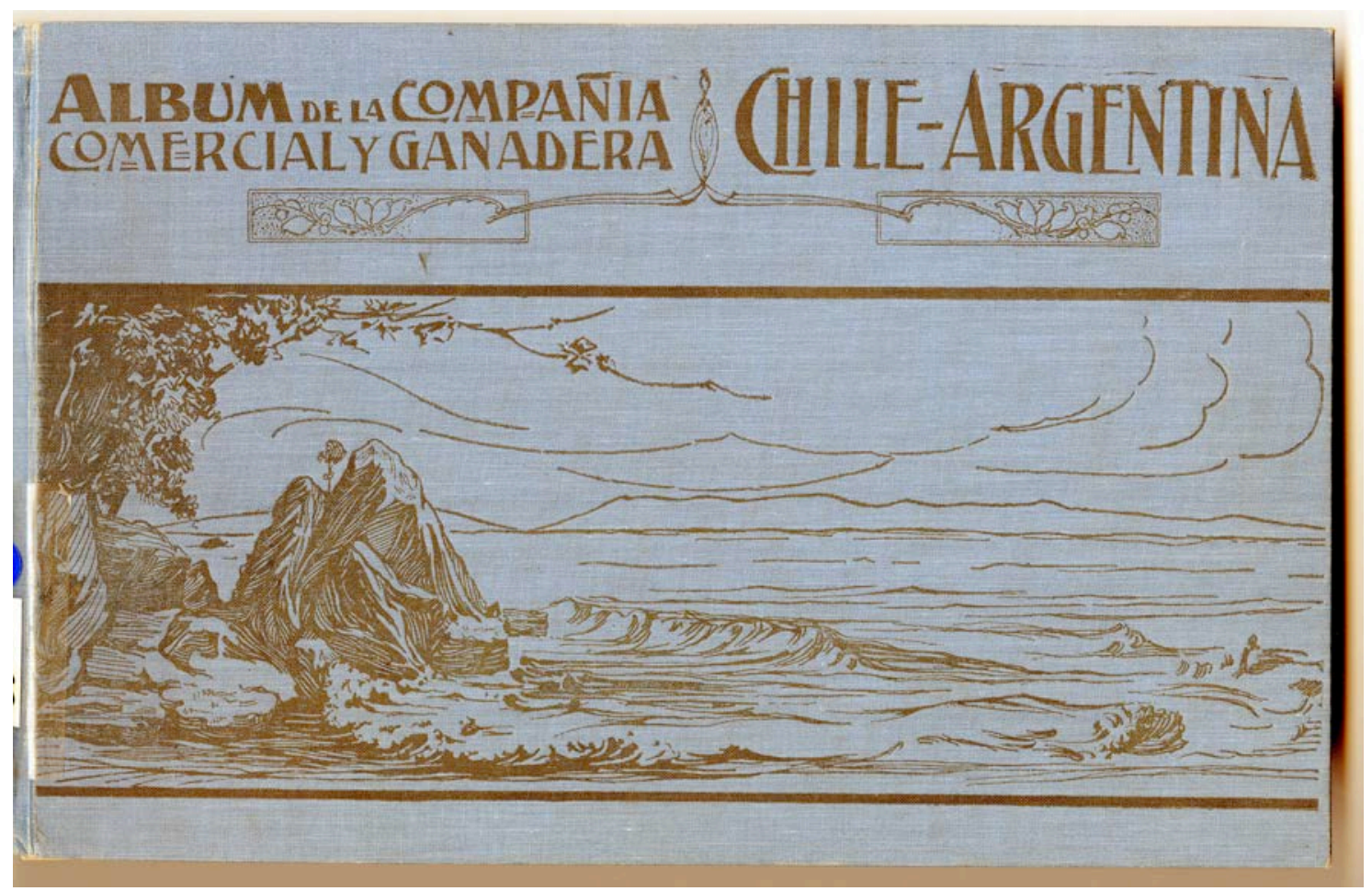

Fig. 8. Portada Álbum de la Compañía Comercial y Ganadera Chile-Argentina, Carlos Foresti, 1910. 
Álbum "Vistas del frigorífico Puerto Bories 1918"

Álbum fotográfico editado en el año 1918 y financiado por la Sociedad Explotadora de Tierra del Fuego, son 75 fotografías distibuidas en 40 hojas.

La Sociedad Explotadora de Tierra del Fuego, fue fundada en 1893 y empezó sus operaciones ganaderas en la Isla de Tierra del Fuego, en 1905 se extendió a los campos pastoriles de la zona de Última Esperanza.

El Frigorífico Bories empezó a trabajar en el año 1910 en la fabricación de carne en conserva, y en 1914 quedó terminado para trabajar con grandes volúmenes de animales en el proceso de refrigeración.

Este compendio de imágenes generado por Foresti describe todo el proceso productivo de la ganadería ovina, además posee abundantes textos, lo que lo hace diferente a otros álbumes, ya que orienta acerca de cada una de las etapas del proceso productivo, la faena de matadero, esquila de lana, curtiembre de cuero y producción de carne en conserva, tal como se aprecia en la siguiete cita:

"Secos los cueros, se les pasa una preparación química la que facilita el pelar la lana; ésta pasa de inmediato a la máquina secadora, y de ésta baja al piso inferior, por medio de un tubo, a la prensa enfardadora". "Una vez pelados los cueros pasan a los tambores lavaderos, y luego a los pozos, después de haber estado en estos el tiempo necesario, pasan a las bateas giratorias para el último lavado" (Álbum Vistas del Frigorífico Puerto Bories 1918).

Las fotografías detallan muy bien las diferentes construcciones complementarias del frigorífico, además de las dependencias que la compañía poseía en Punta Arenas.

\section{Álbum "Territorio de Magallanes 1920"}

Último álbum fotográfico producido por Carlos Foresti, sin lugar a duda es el más completo dentro de su trayectoria en la

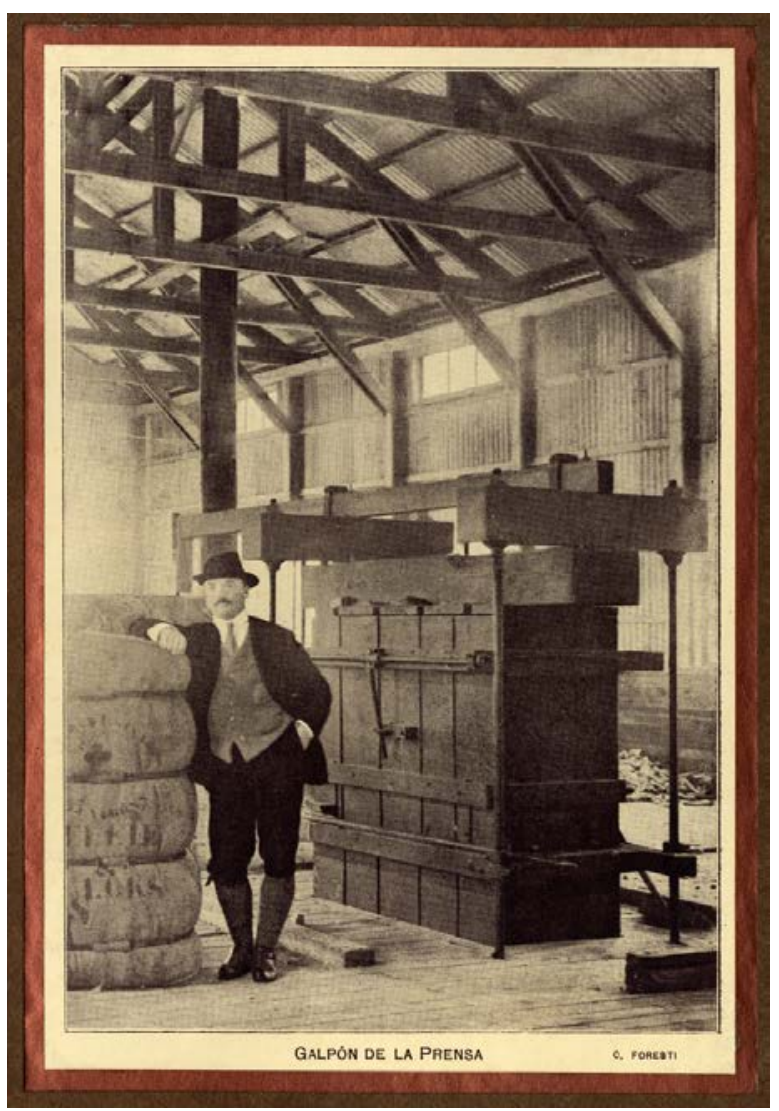

Fig. 9. Galpón de la prensa (enfardadora de lana), muestra a Alejandro Menéndez Behety (propiestario de la estancia Glencross), en Álbum Vistas de las estacias Glencross y Laurita, 1909, Carlos Foresti. 


\section{MARTINOVIC}

elaboración de este tipo de productos, tanto los generados de manera particular, como los financiados por autoridades y/o privados.

Está constituido por 136 hojas con 270 fotografías, muchas de ellas panorámicas de diferentes sectores del territorio de Magallanes, tanto en su carácter rural como urbano, siendo estas últimas las más numerosas.

Posee un elemento muy interesante que funciona a modo de introducción, recogiendo las motivaciones declaradas por Foresti a la hora de emprender la tarea de pubicar el precitado álbum, al respecto señala:

"Impulsado por el deseo de difundir, en forma gráfica, los progresos alcanzados por el Territorio de Magallanes, he confeccionado este Álbum que, aunque modesto en sus proporciones, no dudo tendrá un gran valor para los que, paso a paso y año tras año, han seguido el proceso evolutivo de esta importante zona del país, en todos los órdenes de su actividad.

Si, como espero, no me falta el apoyo de los que con su esfuerzo han contribuido al evidente desarrollo de que hoy puede enorgullecerse, será para mí un poderoso estímulo que me impulsará a proseguir la tarea que me impuse, sin otro anhelo ni ambición que la de cooperar, en la medida de mis fuerzas, a conquistar el lugar prominente que le corresponde".

(Carlos. Foresti, Álbum Territorio de Magallanes 1920).

Carlos Foresti prosigue su descripción realizando una breve pero bastante completa representación de observaciones meteorológicas de la zona, por medio de una narración que continúa en la segunda hoja del álbum, para luego presentar un detallado plano a color de la ciudad de Punta Arenas. Se puede inferir que dicha pieza cartográfica fue creada ex profeso para la ocasión, ya que tiene como leyenda "del álbum de Punta Arenas de C. Foresti." creación basada a su vez, en un Plano editado cinco años antes por Díaz y Contardi Editores.

Prosigue un retrato del Presidente de la República Juan Luis Sanfuentes con un muy particular escudo del Territorio de Magallanes.

Reviste un gran interés la versión que realiza Carlos Foresti del escudo del Territorio de Magallanes, que incluye a continuación del plano de la capital regional magallánica. Creado por decreto en sesión del 07 de Junio de 1899, por la Honorable Comisión de Alcaldes, fue diseñado originalmente bajo el pincel del pintor escenógrafo Natalio Rogolini ${ }^{3}$, y el modelado en yeso de un francés de apellido Baglina. La descripción contenida en el Censo de Lautaro Navarro de 1908 señala:

"el escudo tiene en el cuartel superior un peñón con el Faro Evangelista y un 
vapor navegando. En uno de los cuarteles inferiores, un par de ovejas y en el otro una panoplia, de instrumentos agrícolas e industriales. Uniendo dos ramas de encina, en la parte inferior se ve una cinta con el lema: "Labor Omnia Vincit". Arriba se divisa algunos de los picos de la estrella de Chile".

La acuarela que da comienzo a la obra discrepa mucho del escudo original que hoy es el escudo de la ciudad de Punta Arenas, ya que posee elementos introducidos por el artista que no son propios del diseño de la versión oficial del emblema. Primero y lo más evidente el vapor junto al faro Evangelista es reemplazado por una Carabela. La corona posada en la parte superior del escudo trae inscrita la palabra Magallanes, bajo la cual se divisa el velamen de cinco embarcaciones, aludiendo al descubridor del estrecho que lleva su nombre y al número de naves que conformaban su expedición las cuales se denominaban Victoria, Trinidad, San Antonio, Santiago y Concepción. Además de la presencia en la parte inferior del escudo de la inscripción MDXX, año de la mítica navegación.

Estos elementos nos indican que el escudo del Territorio de Magallanes fue modificado por Foresti para, a modo de homenaje, conmemorar los cuatrocientos años del viaje que descubrió el estrecho de Magallanes e incorporó este territorio al imaginario mundial.

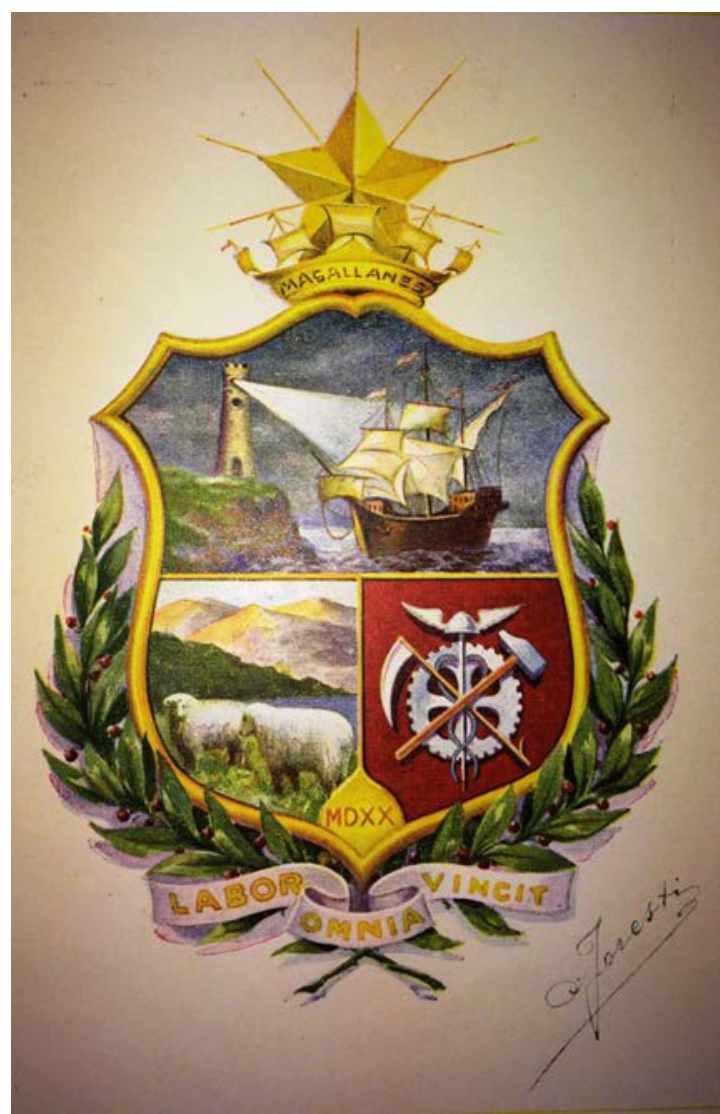

Fig. 10. Escudo del Territorio de Magallanes, en Álbum Territorio de Magallanes, Carlos Foresti, 1920.

La figura de Magallanes como individuo si bien no está representado en el escudo, será el mismo emblema con las citadas modificaciones el que se plasmará en la única obra que se conserva del autor, un retrato de Magallanes.

Es evidente que no es coincidencia, sino un hecho muy bien planificado que este Álbum se enmarque dentro de la serie de propuestas que vienen a conmemorar el cuarto centenario de la hazaña del lusitano descubridor de estos territorios.

\section{La obra pictórica de Foresti}

La segunda vertiente del trabajo de Carlos Foresti en la Patagonia hace referencia a su producción pictórica, poco numerosa ya que el total conocido no sobrepasa las doce piezas. 
Un retrato al óleo y diez paisajes al óleo, al gouach y a la tinta, más un dibujo al carboncillo. De las mencionadas, la primera es la única que se conserva en formato de cuadro, en tanto que de las demás se conoce su existencia, al haber sido reproducidas en revistas y álbumes.

A continuación se detallan sus obras pictóricas:

-Retrato de don Hernando de Magallanes: Corresponde a una pintura de tipo histórico, que representa a Hernando de Magallanes. No está fechada, pero suponemos que debe haber sido creada durante la permanencia de Carlos Foresti en Magallanes, o sea entre el año 1899 y el 27 de julio de 1932, fecha de su fallecimiento (Martinic, 2007, p. 18).

El personaje aparece ubicado justo al centro del espacio de la obra, de pie, de frente, con las $3 / 4$ partes de su cuerpo representado, mirando fijamente al espectador. Con barba poblada y vestido con jubón de pieles. La puesta en escena que lo rodea exhibe diversos elementos que simbolizan su hazaña, una mesa con un mapa desplegado y un compás sobre los cuales posa su mano derecha, más atrás el globo terráqueo y sobre la parte superior izquierda del cuadro el Escudo del Territorio de Magallanes y a la derecha el Escudo de Armas de Magallanes.

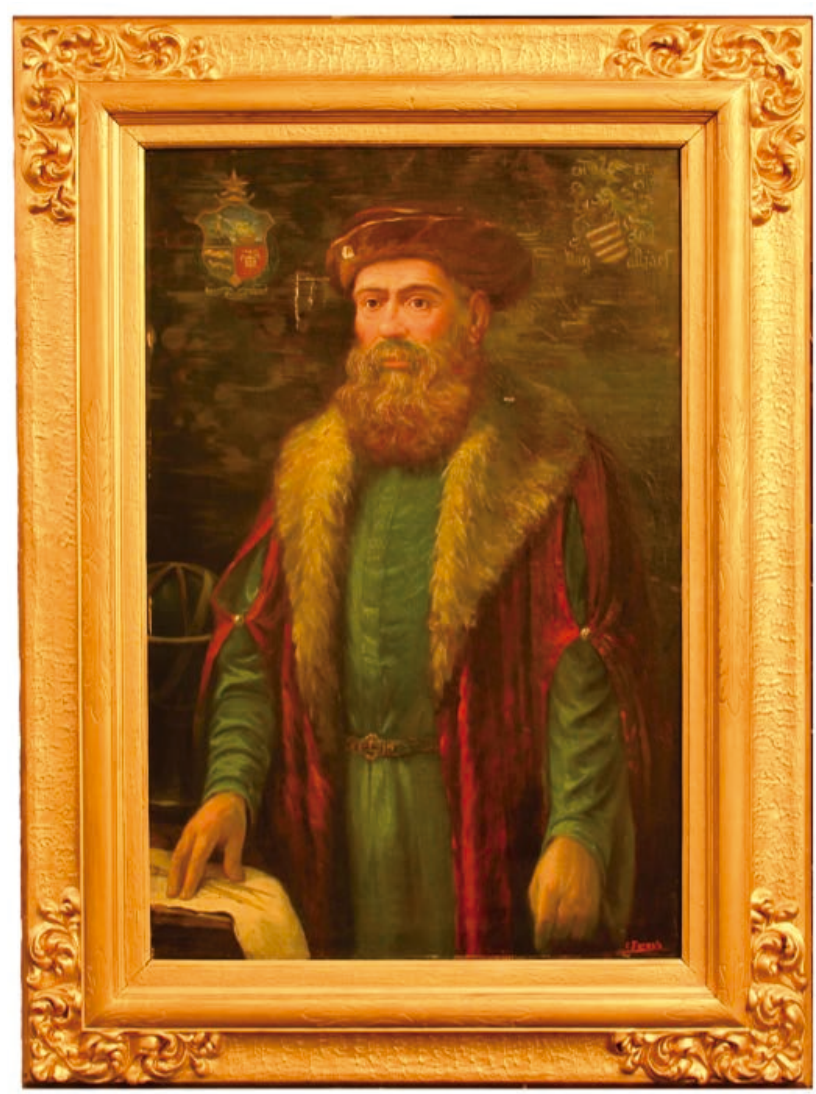

Fig. 11. Retrato de don Hernando de Magallanes, realizado entre los años 1839-1932. Museo Regional de Magallanes.
Hasta el momento no se tienen más datos sobre esta pintura. Probablemente este inspirada en algún grabado o pintura reproducido en algún diccionario o publicación especializada a la que tuvo acceso Foresti. En este sentido, es importante señalar que la figura de Magallanes se ha reproducido iconográficamente, desde el siglo XVI, siguiendo como modelo una obra que actualmente se encuentra presente en el Museo Naval de Madrid. Ésta, a su vez, tiene su origen en una pintura italiana del siglo XVI, atribuida a la escuela de Ángel Broncino, que se encontraba en el palacio ducal de Florencia.

Lo que sí es seguro es que se trata de un original, como lo atestigua la firma de su autor sobre el costado inferior derecho de la tela. Es relevante, por lo tanto, y necesario para el avance del conocimiento en relación a la producción de este artista que se conozca la existencia del retrato. 
Foresti tomó como referente distintas vistas de la región de Magallanes, creando paisajes naturales y culturales. Estas obras no están presentes en originales, sino solamente por medio de las reproducciones que aparecen en el álbum Glencross y Laurita del año 1909, en el Álbum del territorio de Magallanes publicado por el autor en 1920, y en la portada de la Revista Menéndez-Behety, de octubre de 1927, año IV, №46, editada en Punta Arenas.

$\mathrm{Al}$ interior del Álbum del territorio de Magallanes aparecen los siguientes títulos: "En Magallanes", reprodución que corresponde a una marina monocroma que representa un paisaje local; "Cúter en los canales Beagle" paisaje marino al guashe; "Noche de luna en los canales Beagle" dibujo a dos tintas; "Un crepúsculo en San Gregorio" ; "Un alba serena”, "S. A. Importadora y Exportadora de la Patagonia”, título de esta última que alude a la Sociedad Menéndez-Behety, otra de las firmas patagónicas que logró alcanzar gran notoriedad y acumulación de capital.

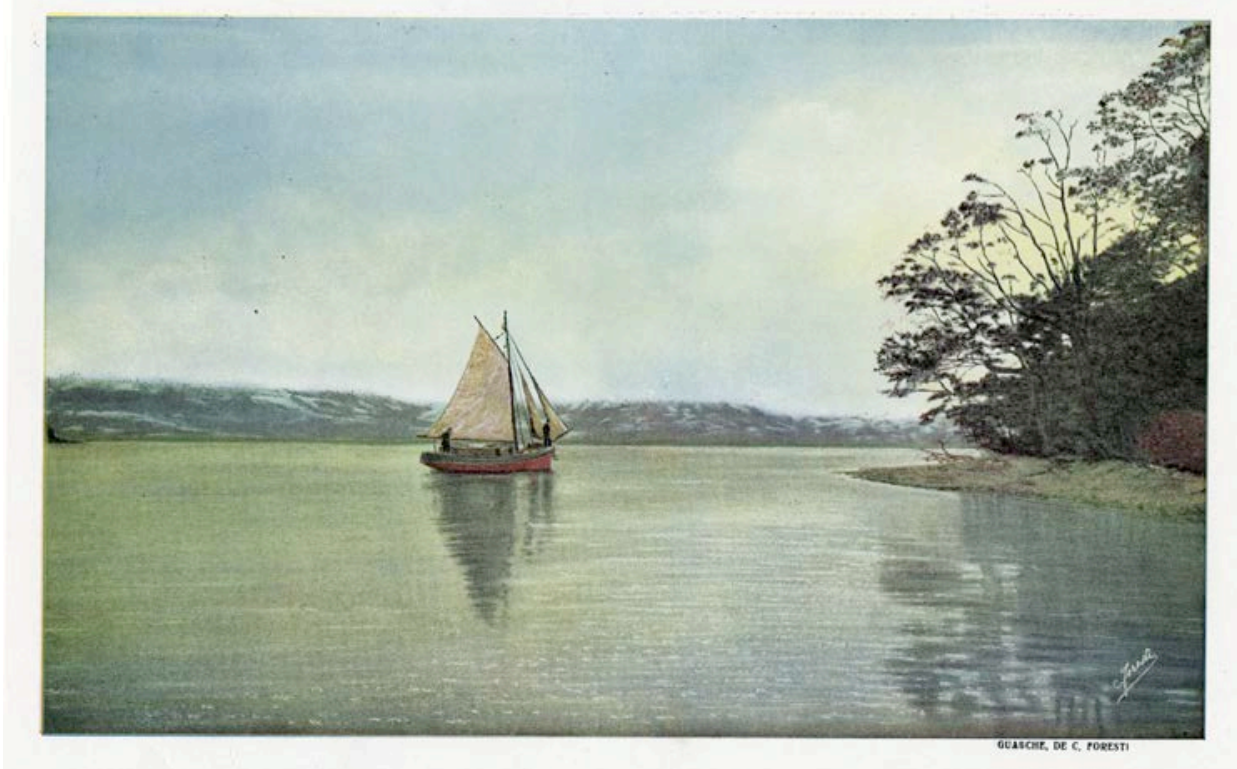

Fig. 12. Cúter en los canales Beagle, en Álbum Territorio de Magallanes, Carlos Foresti, 1920.

En relación a esta última imagen, es sabido que esta sociedad legó a posser una respetable flota de cabotaje y transporte de pasajeros, de modo que esta representación alude posiblemente al "Asturiano". La figura principal exhibe la embarcación de la flota que perteneció desde sus inicios a esta sociedad. Sobre el costado inferior izquierdo de la tela aparece inscrito con letras amarillas la siguiente leyenda, que corresponde a los nombres de los buques: Flota. Argentino, Asturiano, Atlántico, Americano... ; y enfrente, al extremo inferior opuesto, una cinta dorada con letras rojas que dice: S.A. Importadora Exportadora de la Patagonia. Sobre la página del álbum donde está reproducida esta pintura, se puede leer: Línea de navegación a vapor entre Buenos Aires y Punta Arenas; Armadores: Sociedad Anónima Importadora y Exportadora de la Patagonia. 


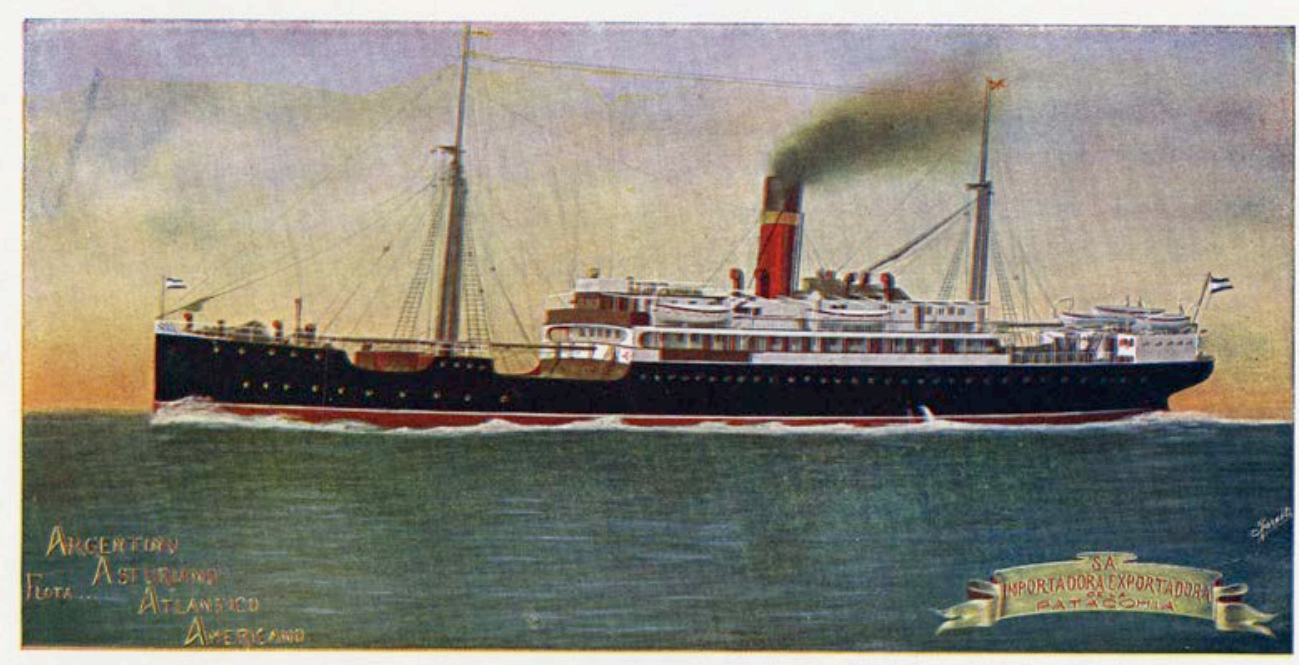

Fig. 13. Flota. Argentino, Asturiano, Atlántico, Americano, en Álbum Territorio de Magallanes, Carlos Foresti, 1920.

\section{CONCLUSIÓN}

Tras la descripción y análisis llevado a cabo respecto del trabajo artístico de Carlos Foresti, desarrollado tanto en la Patagonia argentina como en la chilena, y expresdado en revistas ilustradas, álbumes fotográficos y en obras pictóricas, se comprende y valoriza el significado patrimonial e histórico del escasamente valorado legado del fotógrafo de origen italiano. Se trata de un cúmulo de valiosa información patrimonial, una memoria visual que registra parte importante de los acontecimientos ocurridos durante las dos primeras décadas del siglo XX en esta zona del país, y que por lo tanto, viene a enriquecer su acervo cultural e histórico.

Rescatable resulta también, la incorporación por parte de Foresti de una serie de innovaciones técnicas como el fotomontaje y colotipia, las que se observan al observar y analizar una serie de retoques bastante bien logrados, que el fotógrafo italiano utilizaba para resaltar o añadir detalles y personajes. En el mismo sentido, se puede observar una evolución en las técnicas que manejaba. Verbibracia, en el álbum "Chile - Argentina. Tierra del Fuego. Patagonia. Casa Braun y Blanchard, 1909" encontramos un retrato grupal en el que se han añadido personajes, situación a que a luz de una revisión crítica con las técnicas digitales actuales, se colige que el tratamiento que se le dio a este retoque, fue burdo y mal logrado. En contraposición, en el álbum del año 1920 del Territorio de Magallanes, si se observa con detención algunas imágenes, se aprecia igualmente el uso de retoques, está vez, muy bien logrados, al punto que casi pasan desapercibidos. Esto denota un mejoramiento radical en las técnicas utilizadas por Foresti con el paso del tiempo.

Sin embargo lo anterior, y a la luz de que la mayoría de sus trabajos fueron requeridos 
por parte de importantes personajes y grupos económicos de la época, a saber, José Menéndez, Mauricio Braun, Juan Blanchard, Alejandro Menéndez Behety, y sus correspondientes firmas o sociedades comerciales (Sociedad Anónima Ganadera y Comercial Menéndez Behety; Comercial Braun y Blanchard, entre otras), los que con fines primordialmente publicitarios, encargaban este tipo de ediciones, y en este sentido, la obra artística de Foresti desde un principio fue vista y valorada como la de un fotógrafo comercial.

Nos parece importante relevar y poner en valor el trabajo artístico desarrollado por Foresti, justo ahora que nos acercamos a la celebración del Quinto Centenario del paso de Hernando de Magallanes por el estrecho que posteriormente llevará su nombre.

\section{AGRADECIMIENTOS}

Esta investigación ha sido financiada por el "Fondo de apoyo a la investigación patrimonial de la DIBAM", año 2016, convocado por el Consejo de Investigación del Centro de investigación Barros Arana, Biblioteca Nacional de Chile, a quienes manifestamos nuestro agradecimiento.

\section{REFERENCIAS}

Fuentes Primarias:

Álbum Ana Braun (Archivo fotográfico Museo Regional de Magallanes).

Álbum Chile-Argentina. Tierra del Fuego. Patagonia. (Archivo fotográfico Museo Regional de Magallanes).

Álbum Casa Braun y Blanchard (1909). (Archivo fotográfico Museo Regional de Magallanes).

Álbum Chubut (1903). (gentileza de la Biblioteca "Gabriel A. Puentes” de la Universidad Nacional de la Patagonia San Juan Bosco).

Álbum Estancia Viscachas (1894-1924). (Archivo fotográfico Museo Regional de Magallanes).

Álbum Expedición de Julius Popper (1887). (Archivo fotográfico Museo Regional de Magallanes).

Álbum inauguración monumento a Magallanes. Cándido Veiga (1920). (Archivo fotográfico Museo Regional de Magallanes).

Álbum Puerto Yartou (1915-1935). (Archivo fotográfico Museo Regional de Magallanes).

Álbum Punta Arenas Recuerdo (1900). (Archivo particular Mateo Martinic).

Álbum Vistas de las Estancias "Glencloss y Laurita" (1909) (Gentileza Depto. de colecciones especiales y digitales. Biblioteca Nacional).

Álbum Vistas del Frigorífico Puerto Bories (1918) (Cortesía de Juan Mac-Lean Gómez), 
digitalizado por Duncan S. Campbell. Recuperado de: http:/patlibros.org/vfpb/).

Revista Zig - Zag (1905-1910). (Biblioteca Nacional)

Revista Mireya. Números I, II y III (1919). (Biblioteca Nacional).

Revista Caras y Caretas (1898-1902) (Biblioteca Nacional de España. Colección digital).

Revista Menéndez Behety (1924-1940).

La Revista de Chile, Noviembre (1920), Año II.

Fuentes Secundarias:

Alonso, J. (2014). Mennedez, Rey de la Patagonia. Santiago de Chile: Catalonia.

Aumont J. (1992). La Imagen. Editorial Paidós, España.

Baeriswyl, D. (2001). Arquitectura en Punta Arenas, primeras edificaciones en ladrillos $1892-$ 1935. Punta Arenas: Ediciones del autor.

Braun, A. (1985). Memoria de una vida colmada. Buenos Aires: (Sin editorial).

Harambour, A. (2017). Soberanía y corrupción. La construcción del Estado y la propiedad en Patagonia Austral (Argentina y Chile, 1840-1920). Historia, 50(II), 555-596.

Lucie-Smith, E. (1996). Artes visuales en el siglo XX. Editorial Könemann, Alemania.

Maderuelo, J. (1996). Campo y ciudad (1749-1851). La percepción del paisaje y la formación de la ciudad industrial. Conferencia en vídeo.

Maderuelo J. (2006). El paisaje, génesis de un concepto. Madrid: Abada Editores.

Martinic, M. (2001). Menéndez y Braun. Prohombres Patagónicos. Punta Arenas: Universidad de Magallanes.

Martinic, M. (2013). Punta Arenas Siglo XX. Punta Arenas: La Prensa Austral.

Martinic, M. (2007). Noticias Históricas sobre los inicios de la Pintura Realista en Magallanes (1834-1940). Magallania, 35(1), 5-32.

Rodriguez, H. (2001). Historia de la fotografía, Fotógrafos en Chile durante el siglo XIX. Centro Nacional del Patrimonio Fotográfico, Chile.

Souriau, E. (1998). Vocabulario de Estética, Madrid: Edición Akal.

Villar, A. (2014). De fulanos y atorrantes: El comienzo de la práctica fotográfica en la Patagonia. Entrevista al historiador y fotógrafo chubutense Pablo Lo Presti. Recuperado de: http:// www.querespondaelviento.com.ar/secciones/escuchar/notas/de-fulanos-y-atorrantes 